10 years ESJ

Special edition

\title{
Meaning making in the context of EFL teaching and learning with an artificial intelligence system
}

Simone Tiemi Hashiguti, MA, PhD

Universidade Federal de Uberlândia, Brazil

Cristiane Carvalho de Paula Brito, MA, PhD

Universidade Federal de Uberlândia, Brazil

Rogério de Castro Ângelo, MA

Instituto Federal de Educação,

Ciência e Tecnologia do Triângulo Mineiro, Brazil

Doi: $10.19044 /$ esj.2021.v17n22p19

Submitted: 20 March 2021

Accepted: 25 May 2021

Published: 12 July 2021
Copyright 2021 Author(s)

Under Creative Commons BY-NC-ND

4.0 OPEN ACCESS

Cite As:

Hashiguti, S. T.; Brito, C. C. P., Ângelo, R. C. (2021). Meaning making in the context of EFL teaching and learning with an artificial intelligence. European Scientific Journal, ESJ, 17 (22), 19. https://doi.org/10.19044/esj.2021.v17n22p19

\begin{abstract}
Within the realm of a technological innovation project for the creation of a virtual laboratory for teaching and learning English as a foreign language, this paper explores the discursive-performatic theory on language that is one of the principles guiding the work. Practical examples from the laboratory are described and fundamental concepts are explained. Meaning making in the historical/technological conditions of the laboratory is seen as taking place in the space between the reexamination of ways to teach formal, institutionalized knowledge on language structure while problematizing meanings and social themes, and reflecting on how language creates realities.
\end{abstract}

Keywords: Digital Information and Communication Technology, Foreign Language Teaching from the South, Algorithm, Discourse, Decoloniality 
I'm not violent man Mr. Oxford don

I only armed wit mih human breath

but human breath

is a dangerous weapon

So mek dem send one big word after me

I ent serving no jail sentence

I slashing suffix in self-defence

I bashing future wit present tense

and if necessary

I making de Queen's English accessory/ to my offence (verses from the poem Listen, Mr. Oxford Don, by John Agard)

\section{Introduction}

One of the key questions in the process of creation of a virtual laboratory for learning English as a foreign ${ }^{1}$ language is how meaning making is understood in a general sense, and in the more specific circumstance of human-artificial intelligence (AI) interaction. ELLA: The English Language Learning Laboratory ${ }^{2}$ was primarily conceived for the use of students of the Bachelor's in Education course of English and English Language Literatures - a distance learning course of the Federal University of Uberlândia. The main objective in the laboratory is to provide opportunities for the students to enhance oral communication in English. Being English a foreign language (EFL) generally considered difficult to be learnt/spoken in Brazil (Lima, 2011; Lima, 2009; Hashiguti, 2017), and imagined as even harder to be learnt in the context of distance learning (Brito \& Hashiguti, 2015), the creation of a virtual laboratory was viewed as the most suitable way for the students of the course to practice English speaking. As they are adult individuals who work full time in diverse working hours, finding a common schedule for every student to attend synchronous sessions for English conversation with the course team is nearly impossible, so the use of an artificial intelligence (AI) system able to respond to human input (speech) was seen as a desirable solution in the

${ }^{1}$ The employment of the terms "foreign", "second" and "additional" to qualify English as a language taught in Brazil varies among authors from different epistemologies in the scientific literature. Although "foreign" might be associated to the idea of geographic territories (Leffa \& Ilara, 2014), we understand it materializes both the sense of hostipitality (Derrida, 2003) something in between the hospitable and the hostile, and the ghostly presence of the other, who claims the language as theirs in a political division, with which we associate English in our context of investigation.

${ }^{2}$ Technological innovation project titled Virtual Laboratory for English Learning (Hashiguti, 2015), developed with the support of the Coordination for the Improvement of Higher Education Personnel - Capes, and according to the proposal (Hashiguti, 2015) approved in the CAPES/UAB Notice no. 03/2015. The funding was released in 2017. 
laboratory for the students to carry out their language studies individually, at times that are convenient for them. The focus on oral production in the laboratory is also an attempt to materially respond to the demand for dynamic forms to practice English conversation in a way to try and fulfill what the students frequently refer to as a strong "desire to speak [English] fluently" (Brito \& Guilherme, 2014; 2017). As this paper is written, in 2020, the development of the project is still in course with great effort from the team to implement the complete AI chatbot system. The system as a whole has to: process natural language (oral input by the laboratory users), select a response to the input, transform it in a digital oral sentence, and play it to the user. This configuration demands the combination of different free software and highlevel programming language.

It is worth mentioning that AI has been used by various applications and EFL courses available on the internet. However, as pointed out by Melo (2019), the use of AI in these products frequently comes down to activities such as listening to and repeating sounds, words, and sentences, or choosing exp ressions and alternatives in preprogrammed objective exercises. In these activities, the feedback of the AI is generally a graph marking the level of success of the user or motivational messages and the displaying of charts, scores, and symbolic prizes for the user as different course levels are reached. Melo (2019) concludes that the use of AI technology in these courses does not mean a substantive change in teaching approaches or the emergence of new methods, but a revamping of the customary teaching practices that had been usual with the previous, non-digital, kinds of technology.

At the ELLA project, the AI system was conceived as a virtual tool that can respond to spontaneous speech ${ }^{3}$ and that reflects the aspects of translingualism (Canagarajah, 2017) and transmodality (Hawkins, 2018) that are characteristics of human communication, and in language practices associated to: (a) the discussion and reflection on themes considered as socially relevant, and (b) the acknowledgement of the learner's place of speech (Ribeiro, 2019) as English speakers.

Regarding translingualism and transmodality, Canagarajah (2017) asserts that translingualism refers to the fact that languages are not isolated systems and that people interacting inevitably make use of different strategies and repertoires, mixing them and negotiating meanings to reach common sense and to solve problems. On a similar note, Hawkins (2018) indicates that in the contemporary, globalized and technologized world, humans engage in

\footnotetext{
${ }^{3}$ According to our previous research (Hashiguti, in press), one of the material characteristics of the English spoken by the students of the first class of this Bachelor's course is the lack of spontaneity.
} 
new forms of communication, making use of a mixture of semioses in transmodal practices of connection marked by speed and fluidity. In this sense, in order to provide an enunciative space that promotes oral communication and maintains characteristics of natural language practices, the design and programming rules in the laboratory should, for example, allow oral input in an English language that may carry traces of Portuguese (students' mother tongue), and accept visual and mediatic materials together with the words in a conversation. These features are currently being developed.

Regarding (a), critical analyses of EFL didactic materials available in the global market (Ferreira, 2014; Hashiguti, 2013, 2016) have made visible how they materialize the colonial discourse, as they tend to repeat colonial identifications of gender, race and social class, and as the global northern way of life is projected as an ideal of happiness, civilization and success. This sort of traditional model of didactic contents results from what Pennycook (1998) pointed out as being an intimate relation between the English language and English language teaching to discourses of colonialism. He reminds us of the fundamental dilemma EFL learners are put through: "English is both the language that will apparently bestow civilization, knowledge and wealth on people and at the same time is the language in which they are racially defined." (Pennycook, 1998, p. 4) The objective at ELLA is to make visible and sayable, in the foreign language, meanings that relate to, for example, social identifications of class, gender, age, race, linguistic knowledge, local and global culture, power strategies, etc. in didactic contents and exercises that may help learners understand not only the internal rules of the linguistic system of the English language, but also the broader conditions that cause certain meanings, social categorizations and power relations to emerge, remain or be transformed and how this happens, in terms of language functioning.

Regarding (b), under the consideration that colonial discourses engender voices that are either authorized (white, heteronormative, patriarchal figures) or unauthorized (subaltern and vulnerable racialized and genderized peoples, socially classified individuals and groups) within societies marked by exclusion and inequality, we understand that foreign speakers of English have been historically/discursively positioned in the second category, where their knowledge of the language is constantly put to test and delegitimized (Souza, 2018; Kumaravadivelu, 2016) at the same time the language is directly associated to owners or the so called "native speakers" in a political/force frame that has to be questioned and denaturalized. This political division of speakers and non-speakers of English may severely affect learners, positioning them in the place of the voiceless subaltern (Hashiguti, 2017). Therefore, the computational programming of the AI system and the design of the exercises 
at ELLA are being carefully tailored to allow users to feel comfortable at their attempts on learning how to speak. That means, for example, the construction of an AI system for conversation practice that will operate within the space of intelligibility between languages and the avoidance to oversimplify oral input by the learners as either only right or wrong. That is, the tools in the laboratory are being designed to process the input of the learners as legitimate attempts of communication and as temporary formulations in a learning process, while the didactic contents are being created to invite learners for reflections on how meanings are produced, as explained in the next sections.

From our point of view, language practices favoring (a) and (b) have to be supported by robust theories on language and meaning making. Since the beginning of the ELLA project, various papers have been presented and published to discuss the laboratory proposal and to expose its foundational theories on language, society, foreign language teaching/learning, and computational programming (Hashiguti \& Alves, 2018; Hashiguti et alia, 2019; Hashiguti; Ângelo \& Ângelo, 2020; Hashiguti, 2020, Hashiguti, 2019; Hashiguti \& Ângelo, 2019; Amado, 2020). Due to its complexity, however, this transdisciplinary theoretical framework is better explained if broken down into parts. Thus, if in Hashiguti et alia (2019) the project was explored through a critical view within Applied Linguistics and by the description of general aspects of the didactic content and the technological choices, and in Hashiguti, Ângelo \& Ângelo (2020) the decolonial principle in the construction of the laboratory and its decolonial computational programming were explained, in this paper, the focus is on the reasoning of the discursive-performatic approach on meaning making that, among other principles, also sustains the organization of the didactic contents and the computational programming at ELLA.

From this perspective, learning a foreign language is understood as a conflictive process in which different linguistic structures and discursive memories are at play together with the use of different kinds of technologies and techniques, all of them being mobilized in a broader socio-historical context. Moreover, in the circumstance of the laboratory, where the use of an AI system is made, meaning making has to be observed in the circumstance of humans (understood as subjects occupying historical and discursive positions) interacting with a computational system that also has a discursive dimension (Hashiguti, 2020) that entails rigorous attention and thoughtful programming by the project team. Having epistemic dispositifs to help make a more critical reading on these aspects is of paramount importance. We believe the discursive-performatic theory on meaning making explained in this paper to be a sensible approach on language. The explanation is based on practical examples extracted from the laboratory. 
It is noteworthy to point out that this paper is written by scientific researchers, doing research in a public university where the team members ${ }^{4}$ can work with intellectual freedom and from a political stance of choice, towards social inclusion and visibility, with the opportunity to produce teaching material that is local (Guilherme \& Souza, 2019), and aimed at our local community of speakers. This condition is determining of the characteristics described in the next section and defines the difference between what can be seen as global market-oriented didactic materials, and local, minor ${ }^{5}$ proposals such as this one.

\section{Meaning making between languages and to a software}

In this study, the process of learning to speak English is conceptualized as a practice of tomada da palavra (Serrani, 1998) or "claiming word" in the foreign language. To claim word is to mobilize networks of meanings, memories of utterances that are inscribed in different socio-historical and ideological affiliations, and knowledge of what can be said and how. In terms of language knowledge, it involves the contact between different linguistic systems and different discursive memories (Pêcheux, 2009). For example, it is common to hear Portuguese speakers learning English to enunciate sentences such as "How many years do you have?" for the question "How old are you?", and "I have [number] years old." for what could be expressed as "I am [number] years old". Between the agrammaticality of the second sentence ("I have [number] years old.") in English and the inadequacy of the first ("How many years do you have?") to ask someone's age, it is possible to observe the discursive memory of the Portuguese language being expressed in the linguistic structure of the foreign language: in Portuguese, age is expressed as ownership (years that one gets to have), while in English, it is expressed as a state. Such difference is not only semantic. It refers to how reality is enunciated and understood in each language. These examples make visible translingualism and the complex combination of linguistic structure and discursive memory.

According to Michel Pêcheux's theory of discourse and meaning making $(2009$, 2002), meanings are produced in the overlap between the linguistic and the historical materialities. His concept of discourse as linguistic structure and historical event (2002) expresses the proposition that languages are relatively autonomous systems with phonological, morphological and

\footnotetext{
${ }^{4}$ The transdisciplinary development team is formed by applied linguists, computer scientists, English teachers, and programmers.

5 This term is a reterritorialization of the Deleuzean-Guattarian $(2015 ; 2003)$ concept of "minor language" which, differing from "major languages", are fractured by the practice of their speakers, in a way that it becomes a richer, transformed language.
} 
syntactic rules of their own which, when enunciated in sentences within language practices, are necessarily related to external, more immediate conditions of production, such as who speaks to whom (what discursive positions are involved), when and where - which partially determines how things are said -, as well as to a more abstract condition, that of the historical possibility of meanings, or discursive memory. This rationale explains why language is not a mere code whose smaller parts can be put together just randomly to make sense and why, within a language learning process, as in any other process of meaning making, more than just language structure is involved. The relationship between linguistic structure and discursive memory must also be understood by the conceptualization of speakers as subjects.

The Pecheudian theory pressuposes the discursive memory operates in the level of unconsciousness and that linguistic formulations do not emerge from conscious and controlled communicative acts, but rather by ideological assujettissement, the primary condition for meaning making. The French term can be approximated to the English term "subjection,"6 and makes reference to the Lacanian reading of the Freudian theorization on subjectivity, in the sense that the subject is constituted in and by language, which by definition has an unconscious dimension. In other words, it is in otherness, constituted in the movement of culture, history, ideology, memory, that meanings are produced, given that "language, in a discursive view, is not conceived as something similar to 'a bag of words', since it only functions in the enunciative production of the subjects in contextualized situations." (Serrani, 2020, p. 49)

In analytical terms, what is enunciated by an individual is understood as determined by the "always already there" (Pêcheux, 1982, p. 115) of meanings, the collective palpable memories from which meanings derive and that functions as both an unconscious interpretive frame and guiding map for interactions. The subject, therefore, is not the origin of meanings. Rather, they are discursive positions among other possible discursive positions, performing the language either by reiterating meanings and reenacting power relations that are possible in discursive formations, or by unconsciously resisting to them.

On that matter, Revuz (1998) draws attention to the fact that the learning of a second language may destabilize the subject's psychic bases, causing them to feel strange and uncomfortable with the impossibility of literality between languages and the bodily changes that are necessary to pronounce the sounds of the new language. That can cause them to search for

${ }^{6}$ Criticism on this scholarship of discourse analysis usually refers to misreadings of its concepts, such as the interpretation of ideology being a mask covering some imagined truth, and of the concept of ideological assujettissement as an impossibility of resistance and transformation on the part of individuals (Busnardo \& Braga, 2000; Nascimento, 2019, p. 18).

${ }^{7}$ Our translation from the Portuguese text. 
forms to minimize the effect of strangeness, such as producing formulations that mirror the reality as it is possible in their mother tongues. At the same time, it is also a form to resist change. Thus, formulations such as "How many years do you have?" can materialize an attempt to make meaning in a language that is still being learned, and/or be unconscious resistance towards remitting enunciation to the sayable in the foreign language, a move that demands a momentary surrender and detachment of the subject from the order of their mother tongue.

The Pecheudian theory of meaning making can be useful in the construction of ELLA because programming the AI structured in the form of chatbots, as it has been in this project, calls for a thorough examination of the English linguistic structure to assess possible points of rupture and crisscrossing with the Portuguese language, and in relation to possible discursive threads of meanings. In the 1960s Pêcheux himself created a computational system for discourse analysis (Pêcheux, 1997) called Deredec, a software that would perform non-subjective analyses of discursive data. The conceptualization of a non-subjective form of analysis refers to the understanding of meanings as temporary, political effects that result from interpretative moves of subjects who occupy interchangeable discursive positions. The notion of discursive position helps explain what formulations are expected to occur in different enunciative circumstances and what and how power relations between the speakers take place through movements of repetition, ruptures and slides of meaning. The subject in discourse, therefore, is not equivalent to the individual as an ontological essence, nor to the figure of a person with their intentions. It is a discursive position that function dialogically with other discursive positions, all of them mutually constituted and maintained. These positions can be occupied by different individuals over time.

As ELLA is being constructed by bilingual speakers and teachers of Portuguese and English, formulations such as the above-mentioned hybrid example sentences are being anticipated and considered as possible forms of oral input by the learners when interacting with the AI system, and with the understanding that our AI analysis works at the level of discursive formations imbricated to discursive memories. Consequently, it is necessary to create specific conditions for adequate feedback from the AI to the students, that is, automatic feedback that can both help them learn characteristics of a standard form of English $^{8}$, at the same time that their oral formulations are considered legitimate attempts of communication, and not simplistically framed as errors.

${ }^{8}$ By standard English, we refer to Gupta's still functional definition: "Standard English: (StdE) A variety that exists world-wide in slightly different forms that differ only slightly 
In the laboratory, an adequate response by the AI is considered one that enables the continuity of the conversation flow and that leads the learner to assess their formulations, study the language, and try to come up with other linguistic forms to express what they want to say without being constrained. In the case of translingual sentences such as "How many years do you have?", some variations of answers the AI is planned to perform are: "I believe you're asking me how old I am. If that's right, I am very young. How about you? How old are you?" or "Did you mean to ask me how old I am? If so, I am very young. How about you? How old are you?" and also "Did you mean to ask me my age? If so, I'm very young. How about you? How old are you?". Another possibility of answer, aiming more specifically at calling attention of the student to language adequacy would be: "I'm very young. How about you? How old are you? Also, if I may, for learning purposes, please check the possible forms of asking about one's age in our lessons." It must be pointed out that these answers depend on a variety of circumstances still being investigated by the project team, namely: how the oral input is processed, that is, how much of the sentence is actually processed (which words are transcribed and if the words that were inferred by the language processor allow the identification of the sentence in the chatbot for the selection of an AI answer); how well the system is able to transform the answer selected in the list of prepared answers, in other words, with what quality of digital voice the sentence is transformed in a feedback to the user; how well the computers, processors and system work with regards to internet speed; how well the voice is captured by the computer recorder; how pronunciation affected the language processing, among others. Due to their technical complexity and because of the current status of the AI program, these aspects will be explored in future papers. For the purposes of this paper, this brief conversation example was provided to make visible the discursive view on language, and what is involved in the human-machine interaction and the construction of the chatbot system for educational purposes.

\section{Discourse and performativity in the teaching of English grammar}

It is our understanding that processes of language teaching and learning to take place at ELLA, in our historical conditions, are not easily detached from the modern linguistic interpretive frame within which schooled educated subjects in the western society were constituted and where a formal type of language knowledge emerged, strongly based on normative rules. This type of

(mainly in a small number of lexical, and orthographic features, and in different distribution of perfective and progressive verbs). None of the Standard Englishes are contact varieties. StdE is the variety taught in schools and seen as usual in most writing and formal speech throughout the English speaking world (Gupta, 1997, p. 4). 
schooled knowledge is a type of power over language that cannot or need not be neglected. As much as there are many students who refuse and/or dislike to study grammar rules, there are many who feel more comfortable at learning with explicit reference to metalanguage.

The explanations of the linguistic structure in the laboratory are organized within a discursive frame and by the consideration of the performative characteristic of language. Discourse, as discussed in the previous section, is a functional concept to theorize and analyze processes of meaning making related to discursive formations and discursive positions. Through the idea of discourse, a reassessment of formal, metalinguistic grammar rules is proposed in the contents of the laboratory: phonological, morphological, and syntactic categories are explained in association to possible processes of meaning making and in entanglement to the ideological/political dimension of meanings, with the purpose of understanding how language constructs/shapes our realities and truths. Such formal knowledge, built along the years of linguistic education in the language subjects in K12 school curricula is a form of power schooled subjects already have on language, and it does not have to be refuted or disregarded. As stated by Souza (2019): “[...] languages are metadiscursive regimes that are not only representations of language but also social-institutional instances that produce knowledge about and control language."

Images 1 and 2 were used in explanations in the English Language Structure in the laboratory. Both images are of posters advertising products in the 1950 's in the United States. Image $1^{9}$ presents a hand drawn portrait of a woman. The face is slighted turned to the left, and smiling. The hair is tied at the back but leaving some waves as a common hairstyle at that time. Drawn on the hair, nose and mouth we can see big X markers connected by straight lines to the following phrases written in capital letters: "NICE HAIR"; "NICE EYES", "NICE TEETH". Right below the portrait, it reads: "BUT - these charms may be wasted if she uses the wrong deodorant."

\footnotetext{
${ }^{9}$ In the laboratory contents, images are described for accessibility of people with low vision or who are blind. In some cases, it is also part of analytic exercises and explanations.
} 


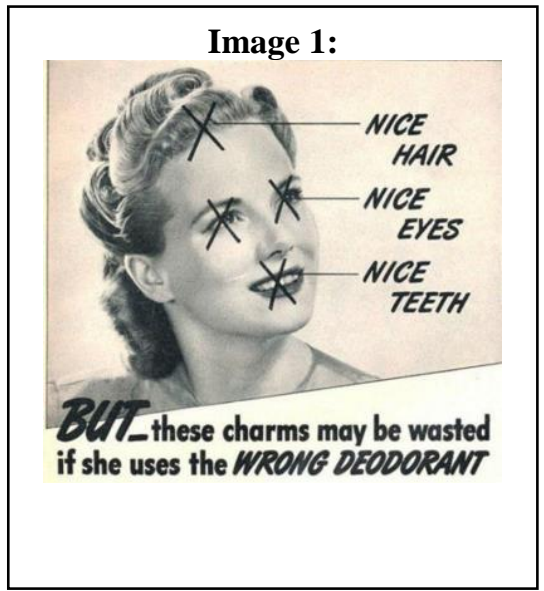

Source:

https://itsblossom.com/blog/2019/06/2 1/offensive-vintage-ads/
Image 2 shows three people standing close to a car, looking at it. Apparently, they could be a couple with their child.
Image 2

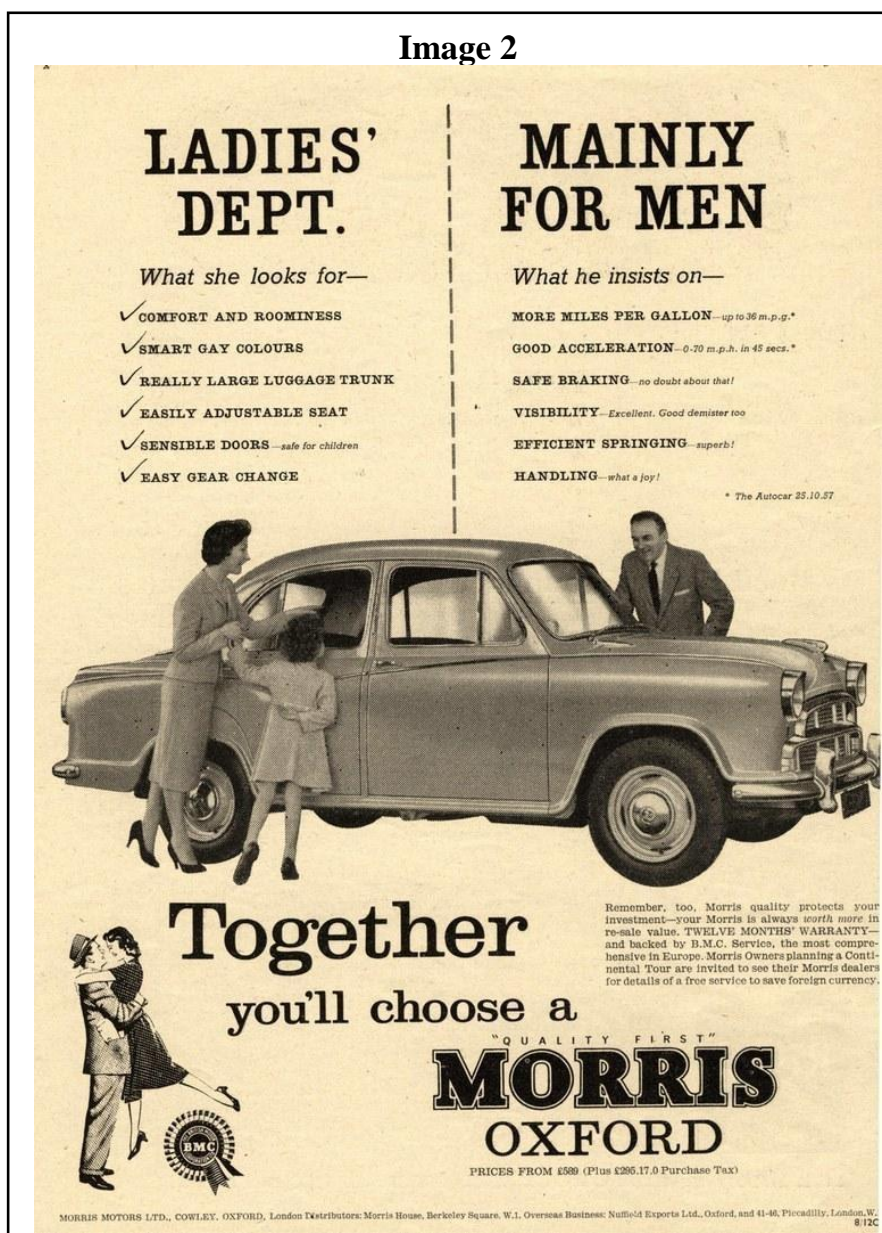

Source: https://teamthunderfoot.com/ideas/the-evolution-ofgender-stereotypes-in-advertising/

Above the photograph, we can read, in the form of two separated lists:

LADIES' DEPT.

What she looks for -

- Comfort and roominess

- Smart gay colours

- Really large luggage trunk

- Easily adjustable seat

- Sensible doors - safe for children

- Easy gear change 


\section{MAINLY FOR MEN}

What he insists on -

- More miles per gallon - up to 36 m.p.g.

- Good acceleration - 0-70 m.p.h in 45 secs

- Safe braking - no doubt about that!

- Visibility - Excellent. Good demister too

- Efficient springing - superb!

- Handling - what a joy!

Right below the photograph of the family, on the left side of the bottom of the poster, there is a drawing of a woman and a man hugging each other. He lifts her up in the air. On the side of this image, it reads: "Together you'll choose a MORRIS OXFORD."

In the contents of the laboratory, the linguistic elements of materials such as Images 1 and 2 that can be regularly classified in formal grammar categories and rules (e.g.: "But", in Image 1, is a coordinating, adversative conjunction; the apostrophe in "Ladies' Dept" refers to a possessive case, etc.) are analyzed as discursive markers that carry the weight of relatively stabilized meanings in certain discourses. In the case of Images 1 and 2, they can be associated to a study on gender discourses. In Image 1, for example, after the list of imagined feminine attributes that are possible in one representation of femininity ("nice hair", "nice eyes", "nice teeth") in a specific discourse, the conjunction "but", in a simple syntactic approach, gives the idea that the subsequent linguistic formulation would be in contrast to the previous linguistic part. However, the formulation that follows: "these charms may be wasted if she uses the WRONG DEODORANT" discursively repeats the discursive objectification of the female body as an object for the male, heteronormative gaze which sees it as purely physical, valued by its appearance and submission to a male referent. So, if syntactically "but" marks opposition of ideas, discursively, it repeats and reaffirms the same meanings expressed in the previous sentences.

The construction of identifications of gender continues in Image 2, where wish lists attributed to women and men legitimate the socially accepted genders in the 1950s, when these ads were produced. As the sentences "What she looks for" and "What he insists on" are in the simple present tense, we understand the effects of the verb tense are the constitution of universal truths about gender. Traditional approaches of the simple present do indicate this verb tense expresses universal truths such as "The sun shines", but hardly ever mention the discursive effect of constitution of social identifications and 
meanings imagined as the truth (and not as created truths) in a historical stratum and in statements such as the ones present in the ads.

Thus, in our approach to formal grammar, the extensive heritage from the linguistic studies to language description and understanding is not denied, but it is localized within broader reflections on discursive practices and meaning making. We claim that simply adding photographs and multimedia materials that make visible social issues in the EFL didactic contents - a usual marketing strategy - is not enough to explain language functioning. By studying language rules and discursive processes, it is believed students have a chance to understand the social and institutional consequences of saying things in different ways, of performing language.

Discourse is thus seen as a conceptual tool with which to understand social categorizations. Regarding the theme of gender, for example, it helps explain why teaching-learning English pronouns is not merely studying a simple grammar category, as gender/personal identifications marked in the pronouns that are available in a language are not unequivocal or literary. Following Butler's (1993) reading on both Austin's theory of perfomativity and Derrida's interpretation of Austin's theory, it is possible to understand that social identifications, such as gender, can be socially imposed, linguistically enunciated, discursively constructed, and performed by different speakers. Put in other terms, enunciating a pronoun to refer to oneself or to another is to perform identification in language: every time one is nominated, categorized, socially shared meanings are (re)enacted, either towards transformation or by repeating crystallized memories, and always dialogically. Performativity, in this sense, refers to the performative characteristic of language and to its capacity to create and maintain realities. Identifying and constructing the other with a pronoun, however, may not necessarily result from conscious acts of speech, but from discursive interpellation or assujettissement. In a conversation, for example, automatically calling someone he or she or they depends on meanings that are possible in different discursive formations with which the individuals identify and which are enacted in the form of discursive positions. Performativity implies both the reiteration of meanings and the possibility of slides. It also refutes essentialist views in which meanings (and the subjects' identifications) are given a priori.

\section{Conclusion}

In the construction of ELLA, the interest is in problematizing the processes of verbal interaction as they take place with processes of noncommunication, misunderstandings, slides of meanings. Therefore, the common didactic idea of progression and linearity that organizes the majority of didactic materials for teaching English is replaced by attempts to describe 
and analyze language from a discursive-perspective approach which calls for a more reflective positioning towards language practices.

In this paper, this approach has been explained with few practical examples from the didactic contents produced for ELLA and for two different sections of the laboratory: the chatbot for human-AI conversation, and the section of English Language Structure. It can be said that the organizing principle of the contents is themed-based and discursively framed. The explanations of formal grammar aspects occupy a secondary role in the laboratory, in the sense that they are not an organizing axis of the units, as usual in tradition language teaching materials.

It should also be inferred that the lessons in the laboratory do not aim at reinforcing colonial dichotomies and naturalized truths, but an invitation for critical positioning regarding language knowledge. Such theoretical inscription can be seen, above all, as a political stance on linguistic education aiming to sustain a theoretical-methodological framework that is responsive to the dynamism and complexity of social life (Moita Lopes, 2006). Due to the complexity of the construction of the AI system, it has been only briefly explained. More extensive considerations will be possible once the laboratory starts running with actual users. However, within the limits of this paper, it can be stated that one of the main aspects for future investigation is the combination of computational programming, language policy as practiced in the lab, and didactic choices in order to actually engage the learners in conversations and in the study of the language and to further EFL oral practice. This possibility does not refer to grammatically accepted formulations only, taking as a parameter normative grammar rules, but to the order of the sayable (Deleuze, 1995), considering the discursive memories at play.

\section{References:}

1. Brito, C. C. de P.; Hashiguti, S. T. (2015). Aspectos discursivos sobre/no ensino-aprendizagem de língua inglesa e na formação de professores em um curso EaD. Revista Horizontes de Linguistica Aplicada, 13(2). https://doi.org/10.26512/rhla.v13i2.1365.

2. Amado, G. T. R. A tomada da palavra no ELLA. Livro de resumos do XVIII Sepella. 2020. 107-107. Retrieved from: http://www.ileel.ufu.br/sepella/wpcontent/uploads/2014/08/CADERNO-SEPELLA-vers\%C3\%A3oFINAL.pdf.

3. Brito, C. C. P. \& Guilherme, M. F. F. (2014) Memorial de aprendizagem e a formação do professor: vozes constitutivas da relação aprender/ensinar línguas estrangeiras. Revista Brasileira de 

LANGUAGE AND EDUCATION: THINKING (AND DOING) OTHERWISE

Linguística Aplicada, v. 14, n. 3, p. 511-532. https://doi.org/10.1590/S1984-63982014000300002.

4. Brito, C. C. P. \& Guilherme, M. F. F. (2017). A constituição do professor de Inglês pré-serviço em um Curso de Letras EaD: representações sobre formação, ensino-aprendizagem e tecnologia. Linguagem em (Dis)curso, v. 17, n. 1, 117-136. https://doi.org/10.1590/1982-4017-170106-3816.

5. Busnardo, J.; Braga, D. B. Uma visão neo-gramsciana de leitura crítica: contexto, linguagem e ideologia. Ilha do desterro: revista de língua inglesa, literaturas em inglês e estudos culturais. N. 38, jan./jul. 2000, 91-114.

6. Butler, J. (1993). Bodies that matter: on the discursive limits of "sex". Routledge.

7. Canagarajah, S. (2017) Translingual practices and neoliberal policies. Attitudes and Strategies of African Skilled Migrants in Anglophone Workplaces. Switzerland: Springer International Publishing AG.

8. Deleuze, G.; Guattari, F. (2015) Kafka: por uma literatura menor. Translated by Cíntia Vieira da Silva. Autêntica Editora.

9. Deleuze, G.; Guattari, F. (2003) A Thousand Plateaus: capitalism and schizophrenia. Translated by Brian Massumi. University of Minnesota Press.

10. Deleuze, G. (1995) Foucault. Brasiliense.

11. Derrida, J. (2003) Da hospitalidade, Anne Dufourmantelle convida Jacques Derrida a falar da hospitalidade. Translated by Fernanda Bernardo. Escuta.

12. Ferreira, A. J. (Ed.) (2014). As políticas do livro didático e identidades sociais de raça, gênero, sexualidade e classe em livros didáticos. Pontes.

13. Guilherme, M.; Souza, L. M. T. M. (Eds.) (2019) Glocal Languages and Critical Intercultural Awareness: The South Answers Back. Routledge.

14. Gupta, A. F. (1997). Colonisation, migration and functions of English. In: Edgar W. Schneider (Ed.) Englishes around the World 1: General Studies, British Isles, North America Studies in Honour of Manfred Görlach (1st. ed., pp. 47-58). John Benjamins.

15. Hashiguti, S. T. Falando com Máquinas: Corpos humanos e artificiais na produção de sentidos em língua estrangeira. [Unpublished manuscript]. Universidade Federal de Uberlândia.

16. Hashiguti, S. T. (2020, 22 October) Ensino-aprendizagem de Inglês entre e por humanos e sistemas de Inteligência artificial [Conference presentation]. Semana Nacional de Ciência e Tecnologia - 
Inteligência Artificial a Nova Fronteira da Ciência Brasileira. IFSC Campus Gaspar / IFG - Campus Posse, Brazil.

17. Hashiguti, S. T.; Ângelo, R. C. ; Ângelo, R. C. (2020) Inteligibilidade entre humanos e máquina no ensino aprendizagem de inglês: uma questão decolonial. Anais do $V$ Colóquio do Grupo de Pesquisa $O$ Corpo e a Imagem no Discurso e IV Simpósio em Transculturalidade, Linguagem e Educação: Thinking (and doing) otherwise. Uberlândia. v. $\quad 1$ 220-240. http://www.ileel.ufu.br/cid/wpcontent/uploads/2020/05/ANAIS-V-CID-e-IV-Simp\%C3\%B3sio.pdf.

18. Hashiguti, S. T.; Brito, C. C. P.; Amado, G. T. R.; Fagundes, I. Z. Z.; Alves, F. S. R. (2019) Thinking and doing otherwise with ELLA - a virtual laboratory for EFL learning. Letras \& Letras, Uberlândia, v. 35, n. especial, 223-246.

19. Hashiguti, S. T.; Alves, F. S. R. (2018, 10 December). ELLA: The English Learning Laboratory. [Conference presentation]. I Workshop de Inovação da Diretoria de Educação a Distância da CAPES, Brasília, Brazil.

20. Hashiguti, S. T. (2017). Can we speak English? Reflections on the unspoken EFL in Brazil. Trabalhos em Linguística Aplicada, 56(1), 213-233. https://doi.org/10.1590/010318135150200431.

21. Hashiguti, S. T. (2016) Uma questão de gêneros: masculino e feminino em lívros didáticos de língua inglesa como língua estrangeira. In M. J. Coracini \& J. S. Cavallari. (Eds.). (Des)Construindo verdade(s) no/pelo material didático: discurso, identidade, ensino (1st ed., pp. 137-154). Pontes.

22. Hashiguti, S. T. (2015) Virtual laboratory for learning English. Project proposal selected in the Notice CAPES/UAB no. 03/2015.

23. Hashiguti, S. T. (2013). O Corpo nas Imagens de Livros Didáticos em Língua Inglesa: repetição e regularização de sentidos. In S. T. Hashiguti (Ed.) Linguística Aplicada e Ensino de Línguas Estrangeiras: práticas e questões sobre e para a formação docente (1st ed., pp. 35-58). CRV.

24. Hawkins, M. (2018) Transmodalities and Transnational Encounters: Fostering Critical Cosmopolitan Relations. Applied Linguistics, Volume 39, Issue 1, 1 February, Pages 55-77. https://doi.org/10.1093/applin/amx048.

25. Kumaravadivelu, B. (2016) The Decolonial Option in English Teaching: Can the Subaltern Act? TESOL Quarterly. Vol. 50, No. 1, March 2016, 66.-85. https://doi.org/10.1002/tesq.202.

26. Leffa, V. J.; Irala, V. B. (2014) O ensino de outra(s) língua(s) na contemporaneidade: questões conceituais e metodológicas. In: Vilson 
J. Leffa; Valesca B. Irala. (Eds.) (1st ed., pp. 21-48). Uma espiadinha na sala de aula: ensinando línguas adicionais no Brasil. Educat.

27. Lima, D. C. (Ed.) (2011). Inglês na escola pública não funciona? Parábola Editorial.

28. Lima, D. C. (Ed.) (2009). Ensino e Aprendizagem de Língua Inglesa: Conversas com especialistas. Parábola Editorial.

29. Melo, M. A. V. (2019) Inteligência artificial e ensino de inglês como língua estrangeira: inovação tecnológica e metodológica/de abordagem? (Unpublished master's thesis). Universidade Federal de Uberlândia, Uberlândia, Minas Gerais, Brasil.

30. Moita Lopes, L. P. Uma linguística aplicada mestiça e ideológica: interrogando o campo como linguista aplicado. In: L. P. Moita Lopes (Ed.) Por uma Linguística Aplicada Indisciplinar (1st. ed., pp. 13-44). Parábola Editorial, 2006.

31. Nascimento, G. (2019) Racismo Linguístico: os subterrâneos da linguagem e do racismo. Letramento.

32. Pêcheux, M. (2009) Semântica e Discurso: uma crítica à afirmação do óbvio. Editora da UNICAMP.

33. Pêcheux, M. (2002) O Discurso: Estrutura ou Acontecimento. Pontes.

34. Pêcheux, M. (1982) Language, Semantics and Ideology. St. Martin's Press.

35. Pêcheux, M. (1997) Análise Automática do Discurso (1969). In: F. Gadet; T. HAK (Eds.) Por uma Análise Automática do Discurso: uma introdução à obra de Michel Pêcheux. (1st ed., pp. 61-162). Ed. da Unicamp.

36. Pennycook, A. (1998). English and the Discourses of Colonialism. Routledge.

37. Revuz, C. A língua estrangeira entre o desejo de um outro lugar e o risco do exílio. In: I. Signorini (Ed.) Língua(gem) e identidade: elementos para uma discussão no campo aplicado.(1st. dd., pp. 213230). Mercado de Letras, 1998.

38. Ribeiro, D. (2019) Lugar de fala. Pólen.

39. Serrani, S. (1998). Abordagem transdisciplinar da enunciação em segunda língua: a proposta AREDA. In: I. Signorini; M. C.Cavalcanti, (Eds.). Linguística Aplicada e Transdisciplinaridade. (1st ed., pp.143167). Mercado de Letras, 1998.

40. Serrani, S. (2020). A proposta multirrede-discursiva: antecedentes, descrição geral e exemplos. In: S. Serrani (Ed.) Cultura e Literatura no ensino de língua-discurso: a proposta multirrede-discursiva na formação docente e no ensino-aprendizagem de línguas materna e estrangeira. (1st ed., pp. 29-63) Pontes Editores. 
41. Souza, L. M. T. M. (2018) The Goan Patient: a cultural speculation. Interdisciplinary Journal of Portuguese Diaspora Studies, v. 07, 413433.

42. Souza, L. M. T. M. (2019) Glocal Languages, Coloniality and Globalization from below. In: M. Guilherme.; L. M. T. M Souza, L. (Eds.) Glocal Languages and Critical Intercultural Awareness: The South Answers Back. (1st ed., pp. 17-41). Routledge. 